\title{
Improving Sugarcane Bagasse as Animal Feed by Ammoniation and Followed by Fermentation with Trichoderma harzianum (In Vitro Study)
}

\author{
Samadi ${ }^{1)^{*}}$, Sitti Wajizah ${ }^{1)}$, Yunasri Usman ${ }^{1)}$, Denny Riayatsyah ${ }^{2)}$, Zidny Al-Firdausyi ${ }^{2)}$ \\ ${ }^{1}$ Animal Husbandry Department, Agricultural Faculty Syiah Kuala University, Banda Aceh \\ 2) Alumni of Animal Husbandry Department, Agricultural Faculty \\ Syiah Kuala University, Banda Aceh \\ *Correspondent author email: samadi177@yahoo.de
}

\begin{abstract}
Sugarcane bagasse is one of agro-industrial residues containing low nutrient content and difficult to be digested by animals. However, it can be recycled to produce value-added product such as protein-enriched animal feed by application feed technology such as ammoniation and fermentation. The purposes of these experiments were to evaluate the quality and in vitro digestibility of sugarcane bagasse by using two steps feed technology process: ammoniation and continued by fermentation process. Two studies were conducted in these experiments. The first study was to determine the quality of amoniated sugarcane bagasse after incubation at room temperature at different days $(0,7,14,21,28$ days) and the second study was to determine in vitro degestibility of ammoniated sugarcane bagasse fermented by using the various levels of sago flour $(0 \%, 5 \%, 10 \%$ and $15 \%$ from sample total) and kept at room temperature for 21 day in an-aerobic condition. Parameters measured in this study were $\mathrm{DM}, \mathrm{CP}, \mathrm{CF}, \mathrm{pH}, \mathrm{OM}, \mathrm{IVDMD}$ (in vitro dry matter digestibility), IVOMD (in vitro organic matter digestibility). The model used for the statistical analysis was completely randomized design (CRD). The results of the first study indicated that length of incubation was not significantly affect $(P>0.05)$ on crude fiber content but had significant effect $(P<0.05)$ on crude protein content but only for control treatment. For the second study concluded that administration of the various levels of sago flour into ammoniated sugarcane bagasse fermented with T.harzianum significantly influenced $(P<0.05)$ on OM, IVDMD and IVOMD but had not significantly effect on $\mathrm{pH}$ value. The results of the study indicated that application $10 \%$ of soluble carbohydrate from sago flour was recommended for fermentation process based on the results of in vitro and fermented feed quality studies.
\end{abstract}

Key Words: ammoniation, fermentation, sugarcane bagasse, quality feed, in vitro

Abstrak. Ampas tebu adalah salah satu hasil produksi limbah industri pertanian dengan kandungan nutrisi dan daya cerna yang rendah. Tujuan dari penelitian ini adalah untuk mengevaluasi kualitas dan daya cerna secara in vitro ampas tebu dengan menerapkan teknologi pakan: amoniasi yang dilanjutkan dengan proses fermentasi. Dua percobaan dilakukan dalam penelitian ini. Percobaan pertama adalah menentukan kualitas dari ampas tebu yang telah diamoniasi dan difermentasi dengan lama pemeraman yang berbeda $(0,7,14,21$ dan 28 hari). Sementara penelitian kedua adalah penentuan daya cerna in vitro dari amapas tebu yang telah diamoniasi dan difermentasi selama 21 hari secara an-aerob dengan level karbohidrat terlarut (tepung sagu) yang berbeda $(0 \%, 5 \%, 10 \%$ dan $15 \%$ dari total sampel). Parameter yang diukur dalam penelitian ini adalah kandungan bahan kering, protein kasar, serat kasar, $\mathrm{pH}$, kecernaan bahan kering dan organik secara in vitro. Rancangan yang digunakan dalam penelitian ini adalah rancangan acak lengkap (RAL). Hasil dari penelitian pertama menunjukan bahwa lama inkubasi tidak berpengaruh $(P>0,05)$ terhadap kandungan serat kasar tetapi berpengaruh nyata $(P<0,05)$ terhadap kandungan protein kasar namun hanya pada protein kasar kontrol. Hasil penelitian kedua dapat disimpulkan bahwa penambahan berbagai level tepung sagu sebagai karbohidrat terlarut pada ampas sagu yang diamoniasi dan difermentasi dengan T.harzianum berpengaruh nyata $(P<0,05)$ terhadap bahan organik, daya cerna bahan kering dan daya cerna organik secara in vitro, tetapi tidak berpengaruh terhadap nilai $\mathrm{pH}$. Hasil penelitian menunjukan bahwa penambahan karbohidrat terlarut tepung sagu sebanyak $10 \%$ direkomendasikan pada proses fermentasi berdasakan hasil positif pada penelitian in vitro dan juga pada kualitas bahan pakan yang diteliti.

Kata kunci: amoniasi, fermentasi, ampas tebu, kualitas pakan, in vitro

\section{Introduction}

Shortage of forages availibility both quality and quantity was the main problem to improve ruminant animals productivity in Indonesia.
One of strategies to solve the problem was to ulilize agricultural and agro-industrial by products as animal feed. However, agricultural and agro-industrial by product feed conteined 
high percentage of fiber and difficult to be digested by animals (Suwandyastuti and Rimbawanto, 2011). Researchs conducted by scientiests indicated that pre-treatment of high fiber feed were able to improve nutrient content and digestibility of feed (Bisaria et al., 1997; Tang et al., 2008; Wanapat et al., 2009 ; Rahman et al., 2011 ; Shrivastava et al., 2011 ; Wajizah et al., 2015 ; Samadi et al., 2015).

One of agro-industrial residues is sugarcane bagasse containing about $50 \%$ cellulose, $25 \%$ hemicellulose and 25\% lignin (Pandey et al., 2000). Sugercane bagasse can be recycled to produce value-added product such as proteinenriched animal feed, enzymes, amino acids, organic acids and compounds of pharmaceutical importance (Pandey et al., 2000). Hartadi et al. (1990) informed that sugarcane bagasse contained low protein content with amount of $3,1 \%$. Application of sugarcane baggase as animal feed has been reported by Okana et al. (2006), in which bagasse cultured with four white-rot fungi (Lentinula edodes, Pleurotus eryngii, Pleurotus salmoneostramineus, Ceriporiopsis subvermispora) at $26^{\circ} \mathrm{C}$ for 8,12 or 16 weeks influencing the in vitro organic matter digestibility (IVOMD) and in vitro neutral detergent fiber digestibility (IVNDFD) with 45.6 and $40.3 \%$ for untreated bagasse respectively and with 68.6 and $59.1 \%, 60.6$ and $49.9 \%$ and 59.9 and $49.0 \%$ for untreated bagasse respectively. Permana et al. (2000) stated that application of sugarcane bagasse supplemented with soyabean meal or wheat bran as substrate of Pleurotus sajor-caju, P. eryngii and Agrocybe aegerita can influence lignin degradation, body production and improve in vitro digestibility.

Research conducted by Soejono (1988) indicated that untreated sugercane baggase had very low digestibility with $16.8-22.2 \%$ due to its high level of lignin. Feed technology should be applied to improve the quality of sugarcane baggase. Fermentation is one of the methods can be applied to increase animal feed quality besides chemical tretament such as ammoniation. Marjuki (2013) stated that chemichal pre-treatment such as ammoniation before fermentation was able to optimize microorganism activities. Trichoderma harzianum ( $T$. harzianum) has been used in fermentation process since it produces cellulotyc enzim that can break down crude fibers to be more available compounds. Research conducted by Mahmilia (2005) indicated that $T$. harzianum was able to reduce crude fiber of water hyacinth (Eichhornia crassipes) about $4.79 \%$ from $26.61 \%$ to $21.82 \%$ after fermentation. Based on the research results, it was concluded that feed technology such as ammoniation and fermentation to be a practical and promising alternative to increase nutritional value of agro residues by product into valuable animal feed. The purposes of these experiments were to evaluate the quality and in vitro digestibility of sugarcane bagasse by using two steps feed technology process: ammoniation and continued by fermentation process.

\section{Materials and Method}

\section{Ammoniation and Fermentation Process of sugarcane baggasse process}

Sugarcane bagasse utilized in this study was collected from local traders at campus area of Syiah Kuala University without determining variety and age of sugercane. Sugarcane bagasse was chopped (Restch SM 200 Rostfrei, Germany) and air-dry up to $10 \%$ DM. Then, chopped sugarcane bagasse was ammoniaed with $4 \%$ of urea $\left(\mathrm{CO}\left(\mathrm{NH}_{2}\right)_{2}\right)$ and solved in water with the comparation of water 1:1 from DM sugarcane baggase and kept at an-aerobic condition for 21 days. The first study to determine the quality of amoniated sugarcane bagasse after incubation at room temperature at different day. The ammoniated sugarcane bagasse was fermented by $10 \%$ of T.harzianum from total DM ammoniated sugarcane bagasse. T.harzianum utilized in this study come from 
plantation protection office in Banda Aceh and it has been cultured by using corn as medium. Before mixing T.harzianum with ammoniated sugarcane bagasse, it was dissolved with aquadest (1:6) and added 10\% molases based on DM. Each $300 \mathrm{~g}$ of sample was added $10 \%$ of sago flour and kept at room temperature for $0,7,14,21,28$ day in an-aerobic condition. For the second study, The ammoniated sugarcane bagasse was fermented by using the various levels of sago flour $(0 \%, 5 \%, 10 \%$ and $15 \%$ from sample total) and kept at room temperature for 21 day in an-aerobic condition.

\section{Chemical Analysis}

Chemical analysis was conducted at Animal Nutrition Laboratory of Bogor Institute Agriculture and Animal Nutrition Laboratory of Syiah Kuala University, Banda Aceh. The chemical content was analyzed for DM , CF, CP (AOAC, 1990). The method to measure in vitro analysis was based on Tilley dan Terry (1963) in which samples were incubated for 24 hours and continued for post rumen digestibility by adding of pepsin for the next 24 hours. Concentration of $\mathrm{pH}$ for in vitro analysis was determined according to Soejono (1996). Measurement of rumen $\mathrm{pH}$ was conducted at the end of every incubation period.

\section{Statistical analysis}

Statistical analyses $(P \leq 0.05)$ was run with the program Statistical Software Package SPSS. The model used for the analysis was completely randomized design (CRD). The following is formula applied for statistical analysis: $\mathrm{Yij}=\mu+$ $\mathrm{Ti}+$ eij, where, Yij was an observation of the dependent variable $\mathrm{ij} ; \mu$ was the population mean for the variable; Ti was the effect of the fermentation, as a fixed effect, and eij was the random error associated with the observation ij. Differences between variables were compared by a one-way analysis of variance (ANOVA). Verification of variance homogeneity and identification of statistical significance was applied by Duncan multiple range test. Observations with $(P \leq 0.05)$ were considered to be statistical significant and trends were declared at $P \leq 0.10$.

\section{Results and Discussion}

\section{Crude Fiber and Crude Protein}

Based on results, incubation time of sugarcane bagasse was not significantly effect on $(P>0.05)$ on ammoniated crude fiber fermented with $T$. harzianum (Figure 1).

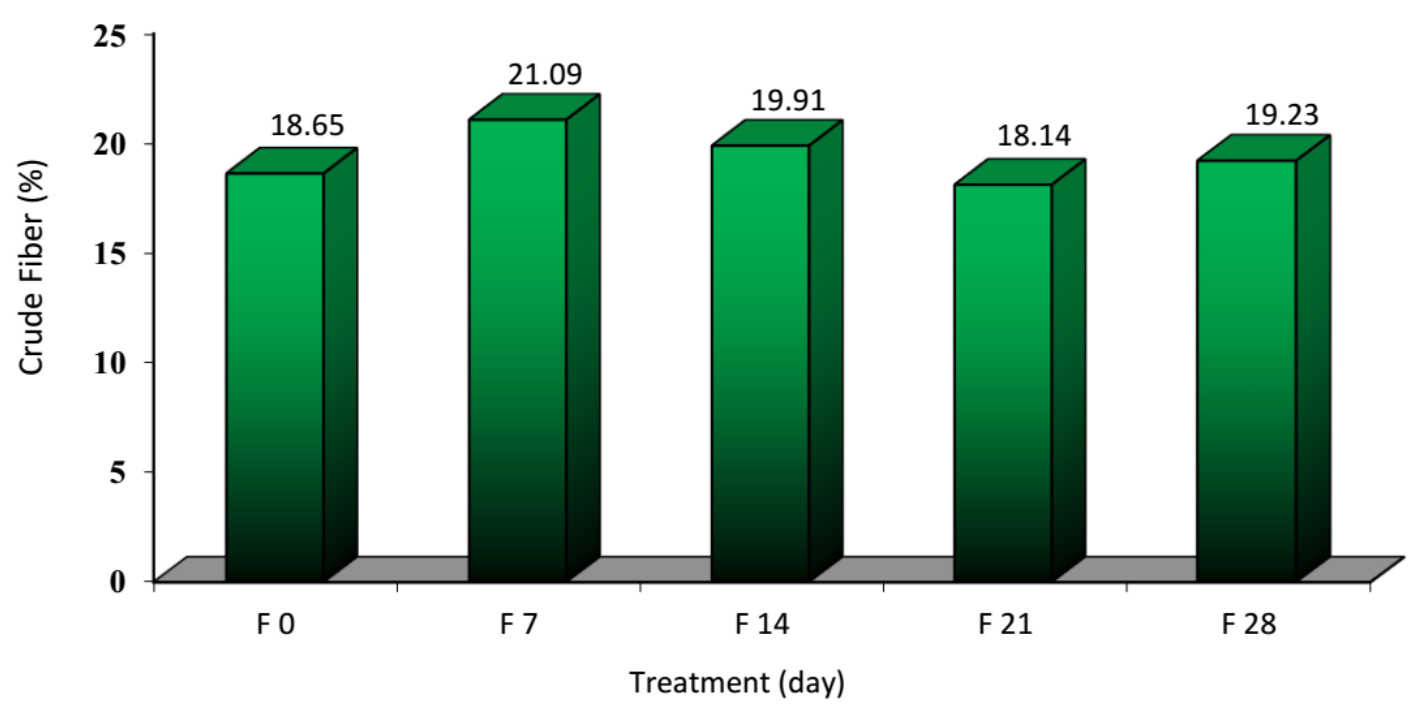

Figure 1. Crude fiber content of ammoniated sugarcane bagasse followed by fermentation with $T$. harzianum at different incubation time $\left(F_{0}=0 d ; F_{7}=7 d ; F_{14}=14 d ; F_{21}=21 d ; F_{28}=28 d\right) n=4$. 
There was no reduction of crude fiber content after $28 \mathrm{~d}$ incubation probably due to strong and very complex bonding system in crude fibers such as cellulose and lignocellulose.

In contrast with the experiments conducted by Nelson and Suparjo (2011) cacao pods fermented with Panerochaeta chrysosporium reduced crude fiber contents as the results of cellulotyc microorganism's activities. In our experiment, before fermentation process the bagasse was ammoniated with $4 \%$ of urea, it might be the cause of no reduction crude fiber in fermented bagasse in this study. Imsya (2005) stated that microorganism population reduced due to poisonous $\mathrm{NH}_{3}$ and it had negative effect on activities of cellulose enzymes. The high content of crude fiber after incubation period has been reported by Hilakore (2008) by using putak fermented with A. niger and $T$. reesei in which the growth of yeast contributed crude fiber content by improving mycelium yeast. In addition, reducing of water content at fermented substrates during fermentation process improved total dry matter content of fermented material (Krisnan, 2006).

In this study, incubation period significantly effect on crude protein content of ammoniated bagasse fermented with $T$. harzianum $(\mathrm{P}<0.05)$ as shown in Figure 2. But the effect was only at control treatment. The research conducted by Yang et al. (2001) corn straw fermented by solid state fermentation (SSF) improved the level of protein from $6.7 \%$ to $14.7 \%$ and decreased the cellulose by $38.0 \%$ and hemicellulose by $21.2 \%$. In addition, urea contributed not only as crude protein improvement but also functioned as protein source for microorganisms to produce true protein. However, it was not measured the true protein content in this study.

In this study (Figure 2) the content of crude protein was higher compared to other treatments. The high level of crude protein content in control was not true protein content instead of crude protein coming from nonprotein nitrogen (NPN) added during ammoniation process before fermentation treatments. This ammonia was not released before fermentation treatments and it was suggested to dry-air longer to release urea before fermentation process. It was indicated from 7 and $28 \mathrm{~d}$ after fermentation, the level of crude protein significantly decreased $(P<0,05)$ compared to control. In accordance with the research conducted by Sujana (2014) ammoniated palm oil fronds fermented with EM4 deceased crude protein content by using urea more than $3 \%$.

Pasaribu et al., (2001) also reported that reducing of crude protein content after 28 weeks incubation period, however after 12 weeks incubation protein content increased to $29.09 \%$. It was probably due to degradation of carbohydrate and other organic materials and resulted in improving the concentration of protein content in the substrate.

The second study was the effect of ammoniated sugarcane bagasse followed by fermentation with $T$. harzianum at various levels of sago flour $(0 \%, 5 \%, 10 \%$ and $15 \%$ from sample total) for 21 day in an-aerobic condition (in vitro study). The results of the second study is presented at Table 1. There was no significant effect $(P>0.05)$ fermentation of sugarcane bagasse at various levels of sago flour on $\mathrm{pH}$ rumen liquor with the range of required rumen fermentation. Usman (2013) stated that crude fiber was effectively degraded at the $\mathrm{pH}$ of $6.8-7.2$ and microorganisms activities will be reduced at the $\mathrm{pH}$ of 6.2 . During fermentation process, there were two important factors namely $\mathrm{pH}$ and incubation temperature. $\mathrm{pH}$ optimal for crude fiber degradation was 6.8 to 7.0 with the temperature of $38-39^{\circ} \mathrm{C}$ (Tilley and Terry, 1963). 


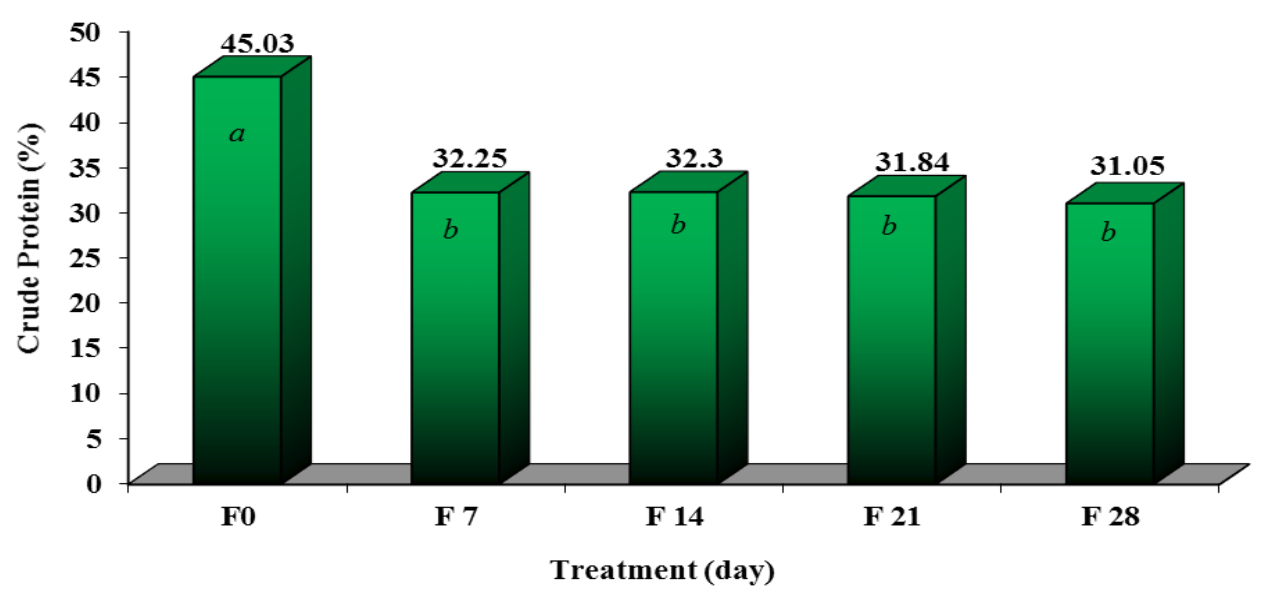

Figure 2. Crude protein content of ammoniated sugarcane bagasse followed by fermentation with $T$.

harzianum at different incubation time $\left(F_{0}=0 d ; F_{7}=7 d ; F_{14}=14 d ; F_{21}=21 d ; F_{28}=28 d\right) n=4$.

Table 1. $\mathrm{pH}$, dry matter, organic matter, IVDMD and IVDOD of ammoniated sugarcane bagasse followed by fermentation with $T$. harzianum at various levels of sago flour $(0 \%, 5 \%, 10 \%$ and $15 \%$ from sample total) for 21 day in an-aerobic condition (in vitro study, $n=4$ ).

\begin{tabular}{|c|c|c|c|c|}
\hline \multirow{2}{*}{ Variables } & \multicolumn{4}{|c|}{ Treatments } \\
\hline & $0 \% \mathrm{SF}^{1)}$ & $5 \% \mathrm{SF}^{11}$ & $10 \% \mathrm{SF}^{1)}$ & $15 \% \mathrm{SF}^{1)}$ \\
\hline $\mathrm{pH}$ & $7,088 \pm 0,038$ & $6,975 \pm 0,025$ & $7,000 \pm 0,029$ & $7,075 \pm 0,048$ \\
\hline Dry matter (\%) & $81,94 \pm 0,243$ & $82,59 \pm 0,550$ & $82,57 \pm 0,456$ & $83,35 \pm 0,093$ \\
\hline Organic matter (\%) & $97,97^{b} \pm 0,054$ & $98,03^{b} \pm 0,039$ & $98,05^{b} \pm 0,032$ & $98,22^{\mathrm{a}} \pm 0,056$ \\
\hline $\operatorname{IVDMD}(\%)^{2)}$ & $56,690^{c} \pm 0,793$ & $62,575^{b} \pm 2,201$ & $69,934^{\mathrm{a}} \pm 1,141$ & $68,170^{\mathrm{a}} \pm 1,436$ \\
\hline IVOMD (\%) & $57,66^{\mathrm{c}} \pm 0,788$ & $63,93^{b} \pm 2,392$ & $71,00^{\mathrm{a}} \pm 1,086$ & $68,79^{\mathrm{a}} \pm 1,380$ \\
\hline
\end{tabular}

${ }^{1)} \mathrm{SF}=$ sago flour

2)IVDMD (in vitro dry matter digestibility) and IVOMD (in vitro organic matter digestibility)

Means within a row with different superscript letters differ significantly $(p<0.05)$

The value of $\mathrm{pH}$, dry and organic matters, IVDMD (in vitro dry matter digestibility) and IVOMD (in vitro organic matter digestibility)

In vitro study of ammoniated sugarcane bagasse followed by fermentation with $T$. harzianum at various levels of sago flour $(0 \%$, $5 \%, 10 \%$ and $15 \%$ from sample total) for 21 day in an-aerobic condition had no significant effect on $(P>0,05)$ on dry matter of ammoniated and fermented sugarcane bagasse. However, IVDMD was significantly different by application of various levels of sago flour (Table 1 and Figure 3). Administration of various sago flour into fermentation media significantly improved $(P<0,05)$ IVDMD of ammoniated and fermented sugarcane bagasse. The highest of IVDMD was at the application of $10 \%$ of sago flour at media with $69.93 \%$. But application of sago flour above $10 \%$ had the same results as $10 \%$ of sago flour at media fermentation.

Research conducted by Wajizah et al. (2015) application of soluble carbohydrates into fermentation media improved IVDMD. It was probably due to availability of nutrients in the in vitro media and resulted in optimum growth of rumen microbial. Harry (2007) stated that availability of energy during fermentation process could be used to improve microbial activities to degraded crude fiber. Increase of rumen bacteria population was strong correlated to fermentation process in using nutrient feed such as cellulose, hemicellulose and other soluble nutrients (Bata, 2008). In addition, Simanihuruk et al. (2008) stated that 


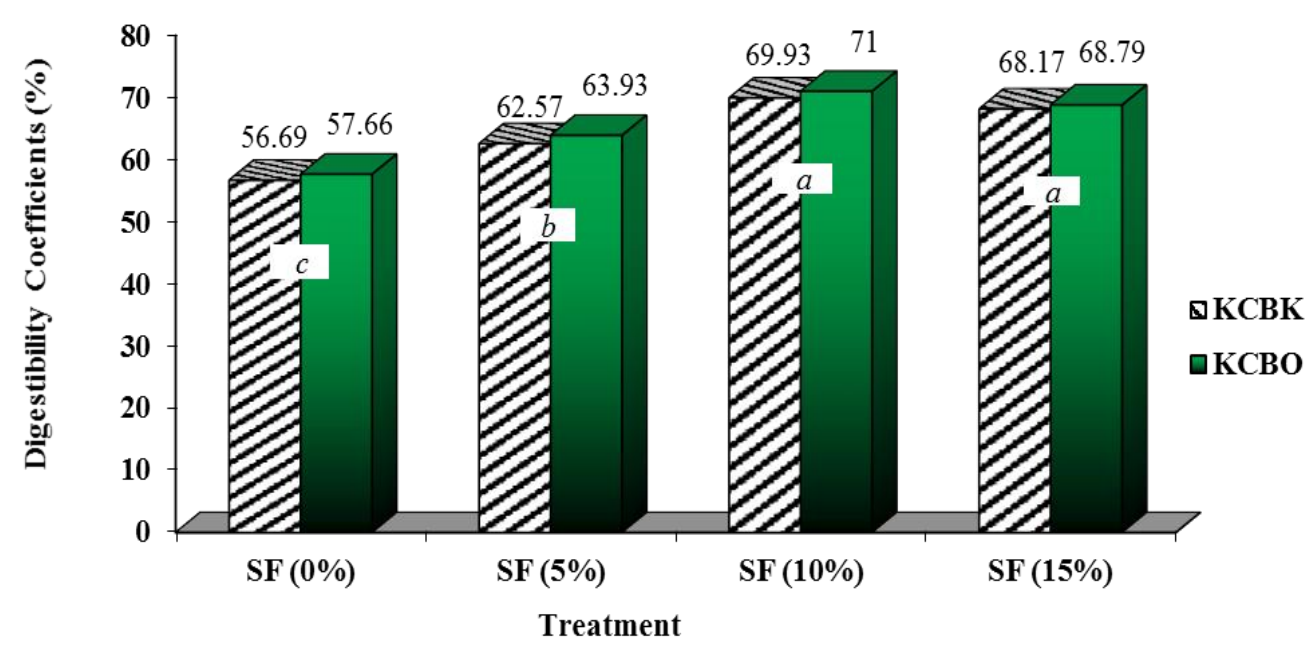

Figure 3. In Vitro Digestibility on various levels of sago flour (KCBK = IVDMD; KCBO = IVOMD)

good results of fermentation influenced by the availability of soluble carbohydrates. Treatments on high fiber contents such as sugarcane bagasse was very crucial to help degradation process since degradability of sugarcane bagasse was very low with 16.8 to 22.29\% (Soejono, 1988). Chandrasari (2011) also stated that digestibility of untreated sugarcane bagasse was low with dry matter digestibility of $21.19 \%$ and organic matter digestibility of $20.92 \%$.

In vitro study of ammoniated sugarcane bagasse followed by fermentation with $\mathrm{T}$. harzianum at various levels of sago flour $(0 \%$, $5 \%, 10 \%$ and $15 \%$ from sample total) for 21 day in an-aerobic condition had significant effect $(P<0.05)$ on organic matter of ammoniated and fermented sugarcane bagasse (Table 1 and Figure 4). The highest organic matter content was application of $10 \%$ soluble carbohydrate with the average value of $98.23 \%$. Research concocted by Wajizah et al. (2015) also indicated that application of soluble carbohydrates significantly effect on organic matter due to crude protein improvement in the substrate. Luh (1991) reported that during fermentation process, yeast growth and microbial protein synthesis from metabolic process caused higher protein content in the substrate.
Administration of various levels of sago flour on ammoniated and fermented sugarcane bagasse significantly influenced $(P<0,05)$ IVOMD at all levels of sago flour. The highest level of IVOMD was by adding $10 \%$ of sago flour in the fermented sugarcane bagasse and tented to reduce after adding of $15 \%$ of sago flour in the fermented sugarcane bagasse. Sabda (2015) reported that administration of more soluble carbohydrates for fermentation might increase crude fiber. Improvement of crude fiber was probably caused by high growth of yeast and it could contribute the high level crude fiber from mycelium (Martieje, 2008).

T. harzianum also produced amylase enzyme to degrade amylopectin compound from sago flour. Okada (1988) reported that T. harzianum was not only function for cellulolityc activities but for hemicellulolityc activity and amylase as well. Application of $15 \%$ sago flour tended to reduce organic matter digestibility, it was due to increase of amylolytic enzymes. In this study, application of $10 \%$ sago flour was the optimum for microorganism degradation both during feed processing and in vitro results. Before study by Sabda (2015) reducing of crude fiber was in accordance with increasing of IVDMD and IVODM at the level of $10 \%$ sago flour. It was probably that by adding $10 \%$ of sago flour will be balance between required energy and 
nitrogen to support the growth of microorganism to degrade substrate. Microbe's activity during fermentation process was influenced by the nutrient availability of substrate and added nutrients in the fermentation media (Khuluq, 2012).

\section{Conclusions}

The results of the first study indicated that length of incubation was not significantly affect $(P>0.05)$ on crude fiber content but had significant effect $(P<0.05)$ on crude protein content but only for control treatment. For the second study concluded that administration of the various levels of sago flour into ammoniated sugarcane baggase fermented with T.harzianum significantly influenced $(P<0.05)$ on OM, IVDMD and IVOMD but had not significantly effect on $\mathrm{pH}$ value. The results of the study indicated that application $10 \%$ of soluble carbohydrate from sago flour was recommended for fermentation process based on the results of in vitro and fermented feed quality studies.

\section{Acknowledgement}

This research has been supported by Syiah Kuala University under the program of Laboratorium Grand at Syiah Kuala University in 2015. The authors thank to Dian Anggraeni at IPB, Iham and M. Hanafiah at Unsyiah for their assistance and chemical analysis.

\section{References}

AOAC. 1990. Officials Methods of Analysis. 15th ed. Association of Official Analytic Chemists, Arlington, VA.

Bata M. 2008. Pengaruh molases pada amoniasi jerami padi menggunakan urea terhadap kecernaan bahan kering dan bahan organik in vitro. Agripet. 8(2): 15-20.

Bisaria R, M Madan and P Vasudevan. 1997. Utilisation of agro-residues as animal feed through bioconversion. Bioresource Technology, 59(1): 5-8.
Chandrasari DP. 2011. Perlakuan Kalsium Hidroksida dan Urea terhadap Kualitas Bagas Tebu.Thesis. Program Pascasarjana, Universitas Gadjah Mada, Yogyakarta.

Hartadi H, S Reksohadiprojo dan A D Tillman. 1990. Tabel Komposisi Pakan untuk Indonesia. Fakultas Peternakan Universitas Gadjah Mada. Yogyakarta.

Harry TU. 2007. Peningkatan Nilai Nutrisi Ampas Sagu (Metroxylon Sp.) Melalui Bio Fermentasi. Balai PengkajianTeknologi Pertanian Papua Barat, Manokwari

Hilakore MA. 2008. Peningkatan kualitas nutritif putak melalui fermentasi campuran Trichoderma reesei dan Aspergillus niger sebagai pakan ruminansia. Disertasi, Sekolah Pascasarjana IPB, Bogor.

Imsya A. 2005. Level Penggunaan Urea Dalam Amoniasi Pelepah Sawit Terhadap Kandungan Bahan Kering, Protein Kasar, Neutral Detergent Fiber (NDF) dan Acid Detergent Fiber (ADF). Fakultas Pertanian Unsri. Indralaya.

Khuluq AD. 2012. Potensi Pemanfaatan Limbah Tebu Sebagai Pakan Fermentasi Probiotik. Halaman 39.

Krisnan R, Ginting dan P Simon. 2006. Pengaruh Fermentasi Menggunakan Beberapa Starin Trichoderma dan Masa Inkubasi Berbeda Terhadap Komposisi Kimiawi Bungkil Inti Sawit, Seminar Nasional Tekhnologi Peternakan dan Veteriner.

Luh B, 1991. Rice Utilization Vol II. Van Nostrand Reinhold, New York.

Mahmilia F. 2005. Perubahan nilai gizi tepung eceng gondok fermentasi dan pemanfaatannya sebagai ransum ayam pedaging. JITV 10(2): 90-95

Marjuki. 2013 Metode pemanfaatan limbah untuk pakan ternak. http://Marjukilecture. Ub.ac.id/. Diakses tanggal: 17 Juni 2014.

Martieje AH. 2008. Peningkatan Kualitas Nutrisi Putak Melalui Fermentasi Campuran Trichoderma risseldan Aspirgillus niger Sebagai Bahan Pakan Ruminansia.Sekolah pasca sarjana IPB. Bogor.

Nelson dan Suparjo. 2011. Penentuan Lama Fermentasi Kulit buah Kakao dengan Phanerochaete chrysosporium: Evaluasi Kualitas Nutrisi Secara Kimiawi. Agrinak Vol. 01 No.01 September $2011: 1-10$.

Okano K, Y lida, M Samsuri, B Prasetya, T Usagawa and $\mathrm{T}$ Watanabe. 2006. Comparison of in vitro digestibility and chemical composition among sugarcane bagasses treated by four white-rot fungi. Animal Science Journal. Volume 77, Issue 3 :308-313.

Okada G. 1988. Cellulase from Trichodermaviride .Methods Enzymol. 160:259-263. 
Pasaribu T, T Purwadaria, AP Sinurat, J Rosida dan DOD Saputra. 2001. Evaluasi Nilai Gizi Lumpur Sawit Hasil Fermentasi dengan Aspergillus niger Pada Berbagai Perlakuan Penyimpanan. Jurnal Ilmu Ternak dan Veteriner 6(2).

Pandey A, CR Socco, P Nigam, and VT Soccol. 2000. Biotechnological potential of agro-industrial residues. I: sugarcane bagasse. Bioresource Technology. 74(1):69-80.

Permana I, G Flachowsky, U Meulen, F Zadrazil. 2000. Use of sugarcane bagasse for mushroom and animal feed production. In Science and cultivation of edible fungi. Proceedings of the 15th International Congress on the Science and Cultivation of Edible Fungi, Maastricht, Netherlands, 15-19 May, 2000. Ed. Griensven, L. J. L. D. Van. Netherlands.

Rahman MM, M Lourenco, HA Hassim, JJP Boars, ASM Sonnenberg, JW Cone, J De Boever and V Fievez. 2011. Improving ruminal degradability of oil palm fronds using white rot fungi. Anim. Feed. Sci. and Tech. 169(3-4):157-166.

Samadi, S Wajizah and Sabda. 2015. Peningkatan kualitas mpas tebu sebagai pakan ternak melalui fermentasi dengan penambahan level tepung sagu yang berbeda. Agripet. 15(2):104-111.

Sabda. 2015. Evalusi Kualitas Ampas Tebu yang Difermentasi dengan Trichoderma harzianum pada Berbagai Level Tepung Sagu. Sekripsi. Jurusan peternakan Universitas Syiah Kuala. Banda Aceh

Shrivastava B, S Thakur, Y Pal Khasa, A Gupte, AK Puniya and RC Kuhad. 2011. White-rot fungal conversion of wheat straw to energy rich cattle feed. Biodegradation. 22(4):823-831.

Simanihuruk K, Junjungan dan SP Ginting. 2008. Pemanfaatan Silase Pelepah Kelapa Sawit Sebagai Pakan Basal Kambing Kacang Fase Pertumbuhan. Seminar Nasional Teknologi Peternakan dan Veteriner. Hal. 446- 455.
Soejono M. 1996. Analisis dan Evaluasi Pakan. Petunjuk Laboratorium. Fakultas Peternakan UGM, Yogyakarta.

Suwandyastuti and Rimbawanto. 2011. Pemanfaatan Limbah Berserat Dalam Konsentrat Untuk Sapi Jantan Umur Satu Tahun. Agripet. 11(1):1-4

Sujana H. 2014. Evaluasi Kandungan Nutrisi Campuran Daun dan Pelepah Sawit Diamoniasi dan Difermentasi Menggunakan Efektif Mikroorganisme (EM4). Skripsi Sarjana Jurusan Peternakan Fakultas Pertanian. Universitas Syiah Kuala. Banda Aceh.

Tang SX, GO Tayo, ZH Tan, LX Shen, CS Zhou, WJ Xiao, XF Han and SB Shen. 2008. Effects of yeast culture and fibrolytic enzyme supplementation on in vitro fermentation characteristics of lowquality cereal straws. J. Anim. Sci. 86(5):11641172.

Tilley JMA and RA Terry. 1963. A two stage technique for the in vitro digestion of forage crops. J. Br. Grass: 18:104-112

Usman Y. 2013. Pemberian Pakan Serat Sisa Tanaman Pertanian (Jerami Kacang Tanah, Jerami Jagung, Pucuk Tebu) Terhadap Evolusi pH, N-NH Dan VFA di dalam Rumen Sapi . Jurnal Agripet. 13(2):53-58.

Wajizah S, Samadi, Y Usman and E Mariana. 2015. Evaluasi Nilai Nutrisi dan Kecernaan In Vitro Pelepah Kelapa Sawit (Oil Palm Fronds) yang Difermentasi Menggunakan Aspergillus niger dengan Penambahan Sumber Karbohidrat yang Berbeda. Agripet. 15(1): 13-19

Wanapat M, S Polyrach, K Boonnop, C Mapato and A Cherdthong. 2009. Effect of treating rice straw with urea and calcium hydroxide upon intake, digestibility, rumen fermentation and milk yield of dairy cows. Livest. Sci. 125:238-243.

Yang X, H Chen, H Gao, Zuohu. 2001. Bioconversion of corn straw by coupling ensiling and solid-state fermentation. Bioresource Technology. 78(3): 277-280. 